\title{
TREND OF HEPATITIS B AND HEPATITIS C INFECTIONS IN A TERTIARY CARE MEDICAL INSTITUTE IN EASTERN INDIA
}

\author{
Supriya Laifangbam1, Gurumayum Preeti2, Vyas Khongbantabam ${ }^{3}$ \\ ${ }^{1}$ Associate Professor, Department of Microbiology, Jawaharlal Nehru Institute of Medical Sciences (JNIMS), Manipur, India. \\ ${ }^{2}$ Demonstrator, Department of Microbiology, Jawaharlal Nehru Institute of Medical Sciences (JNIMS), Manipur, India. \\ ${ }_{3}^{3}$ Assistant Professor, Department of Surgery, Jawaharlal Nehru Institute of Medical Sciences (JNIMS), Manipur, India.
}

\begin{tabular}{l}
\hline ABSTRACT \\
BACKGROUND \\
In Manipur, one of the six high HIV-prevalence states of India, information is limited regarding Hepatitis B and C infections, \\
which share a similar parenteral mode of transmission.
\end{tabular}

\section{AIMS}

To investigate the trend of Hepatitis B surface antigen (HBsAg) and Hepatitis C antibodies (HCVAb) and to identify the seropositivity rates at different age-groups.

\section{SETTING \& DESIGN}

A retrospective cross-sectional study was conducted at the Microbiology Department of a Tertiary Care Medical Institute on existing data from 2010-2015.

\section{MATERIALS \& METHODS}

Serum samples were screened for HBsAg and HCVAb using rapid immunochromatography tests and 3rd generation enzymelinked immunosorbent assays (ELISA).

\section{STATISTICAL ANALYSIS}

The prevalence of both hepatitis B and C infections were analysed by using Student's t-test at probability level of 5\%. A P-value of less than or equal to 0.05 was considered statistically significant.

\section{RESULTS}

The data of 37352 serum samples were collected. $250(2.4 \%)$ and 552 (5.4\%) of 10121 males were positive for HBsAg and HCVAb respectively, and $132(0.8 \%)$ and $78(0.5 \%)$ of 16568 females were positive for HBsAg and HCVAb respectively. 43 (0.42\%) males and $12(0.04 \%)$ females were positive for both infections. For HBsAg, the yearly seroprevalence ranged from 1.55 to $4.2 \%$ among the males and from 0.66 to $1 \%$ among the females. For HCVAb, it ranged from 3.91 to $8.17 \%$ among the males and from 0.30 to $0.64 \%$ among the females. Difference in seroprevalence between males and females were found to be statistically significant at $\mathrm{P}$-value $<0.05$. Seropositivity rates were maximum at $41-50$ years for both infections among positive males, and at $21-$ 30 years for HBsAg and 31-40 years for HCVAb among positive females.

\section{CONCLUSION}

The rising seroprevalence rates of both hepatitis infections, especially those of HCV infection among the males need urgent attention.

\section{KEYWORDS}

Enzyme Linked Immunosorbent Assay, Hepatitis B, Hepatitis C, Immunochromatography, Seroprevalence.

HOW TO CITE THIS ARTICLE: Laifangbam S, Preeti G, Khongbantabam V. Trend of hepatitis B and hepatitis C infections in a tertiary care medical institute in Eastern India. J. Evolution Med. Dent. Sci. 2016;5(35):2061-2064, DOI: $10.14260 /$ jemds/2016/483

\section{INTRODUCTION \\ Hepatitis B Virus (HBV), Hepatitis C Virus (HCV), and Human Immunodeficiency Virus (HIV) infections are global public health problems, affecting millions of population worldwide. Epidemiological studies show wide variations in the prevalence patterns of the HIV, Hepatitis B and the Hepatitis $C$ Virus infections. Prevalence of these infections may vary not only from country to country but also in different regions of the same country.}

Financial or Other, Competing Interest: None.

Submission 12-03-2016, Peer Review 09-04-2016,

Acceptance 13-04-2016, Published 02-05-2016.

Corresponding Author:

Dr. Supriya Laifangbam,

BSCC, Uripok Flyover Point,

Imphal West-795001,

Manipur.

E-mail: slaifangbam@gmail.com

DOI: $10.14260 /$ jemds $/ 2016 / 483$
Manipur is one of the six high prevalence states in India regarding HIV infection. The rationale of this study is that HIV, HBV and HCV all share a common route of parenteral transmission. Hepatitis B and C affect the liver chronically and hence is a cause of high morbidity and mortality. The purpose of this study is to estimate the seroprevalence of hepatitis $\mathrm{B}$ and hepatitis $\mathrm{C}$ infections among individuals attending our medical institute in the capital of this state and to identify the seropositivity rates at different age groups of infected persons.

\section{MATERIALS AND METHODS}

The study was carried out in the Serology and Immunology section of the Department of Microbiology in a Tertiary Medical Institute in Eastern India. It was a retrospective cross-sectional data review, and the identity of the patients had been delinked from the data. 
Data evaluated included age, sex and the findings of blood tests from all individuals who registered consecutively at the Out-Patient Department (OPD) or were admitted to the In-Patient Department (IPD), from January 2010 to December 2015 and who were advised to undergo screening for Hepatitis B surface antigen (HBsAg) and Hepatitis C virus antibodies (HCVAb). About $5 \mathrm{~mL}$ of venous blood was received from each individual and the blood was allowed to clot for 30 minutes at room temperature.

The serum sample was separated after centrifugation at low speed. The serum was tested for HBsAg by using a rapid care method (Hepacard, manufactured by Biomed Industries/Diagnostic Enterprises, India). Reactive samples were confirmed by another rapid test (Hepaview, manufactured by Qualpro Diagnostics, India) or by an Enzyme Linked Immunosorbent assay (ELISA) (Hepalisa, manufactured by J. Mitra and Co. Pvt Ltd., India). Antibodies to HCV were determined using rapid test device (FlavicheckHCV WB, manufactured by Qualpro Diagnostics, India).

Samples reactive by this test were confirmed using another rapid test (HCV Tridot, manufactured by Diagnostic Enterprises, India) or by a $3^{\text {rd }}$ generation ELISA (SD HCV ELISA 3.0, manufactured by Standard Diagnostics, Inc., Korea). All the tests were performed in accordance with the manufacturer's instructions using adequate controls. A patient is considered positive for any one or both of these infections if at least two of three tests used for each type of infection were reactive. The prevalence of both hepatitis $B$ and $\mathrm{C}$ infections were analysed by using Student's t-test at probability level of 5\%. A P-value of less than or equal to 0.05 was considered statistically significant.

\section{RESULTS}

Of 37417 consecutive blood samples received over a period of six years, eleven failed to produce adequate amount of serum for the tests, and 54 were considered not fit for the tests as they were haemolysed. A total of 37352 serum samples were included in the study. Table 1 shows the yearwise distribution of individuals screened for HBsAg and HCVAb in terms of gender and type of hospital attendance (In-patient and Out-patient). Females (73\%) outnumbered males (27\%). Table 2 shows the year-wise seropositivity rates of HBsAg and HCVAb. Over a period of six years from 2010 and 2015, not only can we see a steady increase in the number of individuals screened, but an overall increase in the percentage of positivity rates for both sexes.

Out of 10121 males screened, 293 (2.9\%) were HBsAg positive and 595 (5.8\%) were HCVAb positive. Out of 27296 females screened, $250(0.9 \%)$ were HBsAg positive and 161 $(0.6 \%)$ were HCVAb positive. The difference in the seroprevalence of HBsAg between the male and the female patients was found to be statistically significant for all six years of the study at $\mathrm{P}$-values of $<0.05$. The corresponding $\mathrm{P}$ values for HCVAb were all statistically significant at zero. Table 3 shows the seropositivity rates of positive patients in different age groups for both infections.

Among the males, the highest seroprevalence for both HBsAg and HCVAb were found to occur in the 41-50 years age group. Among the females, the highest seroprevalence for both HBsAg and HCVAb were found to occur in the 21-30 and 31-40 years age groups respectively.

\begin{tabular}{|c|c|c|c|c|c|}
\hline Year & Total & Male & Female & Outpatient & Inpatient \\
\hline 2010 & 4084 & 767 & 3317 & 3069 & 1015 \\
\hline 2011 & 4560 & 1100 & 3460 & 3536 & 1024 \\
\hline 2012 & 5978 & 1368 & 4610 & 4556 & 1422 \\
\hline 2013 & 6736 & 1555 & 5181 & 5079 & 1657 \\
\hline 2014 & 7966 & 1913 & 6053 & 6114 & 1852 \\
\hline 2015 & 8028 & 1852 & 6176 & 6133 & 1895 \\
\hline \multicolumn{7}{|c|}{ Table 1: Year-Wise Distribution of } \\
Individuals Screened for HBsAg and HCVAb \\
\hline
\end{tabular}

\begin{tabular}{|c|c|c|c|c|c|c|}
\hline \multicolumn{7}{|c|}{ Yearly Positivity Rates N (\%) } \\
\hline $\begin{array}{c}\text { Test/ } \\
\text { Sex }\end{array}$ & 2010 & 2011 & 2012 & 2013 & 2014 & 2015 \\
\hline \multicolumn{7}{|l|}{ HbsAg } \\
\hline Male & $\begin{array}{c}14 \\
(1.83)\end{array}$ & $\begin{array}{c}17 \\
(1.55)\end{array}$ & $\begin{array}{c}28 \\
(2.05)\end{array}$ & $\begin{array}{c}37 \\
(2.38)\end{array}$ & $\begin{array}{c}75 \\
(3.9) \\
\end{array}$ & $\begin{array}{c}79 \\
(4.2) \\
\end{array}$ \\
\hline Female & $\begin{array}{c}22 \\
(0.66)\end{array}$ & $\begin{array}{c}23 \\
(0.66)\end{array}$ & $\begin{array}{c}40 \\
(0.87)\end{array}$ & $\begin{array}{c}52 \\
(1.00)\end{array}$ & $\begin{array}{c}48 \\
(0.79)\end{array}$ & $\begin{array}{c}53 \\
(0.85) \\
\end{array}$ \\
\hline Total & $\begin{array}{c}36 \\
(0.88) \\
\end{array}$ & $\begin{array}{c}40 \\
(0.88)\end{array}$ & $\begin{array}{c}68 \\
(1.14)\end{array}$ & $\begin{array}{c}89 \\
(1.32)\end{array}$ & $\begin{array}{c}123 \\
(1.5)\end{array}$ & $\begin{array}{c}132 \\
(1.6) \\
\end{array}$ \\
\hline \multicolumn{7}{|c|}{ HCVAb¥ } \\
\hline Male & $\begin{array}{c}34 \\
(4.43)\end{array}$ & $\begin{array}{c}43 \\
(3.91)\end{array}$ & $\begin{array}{c}76 \\
(5.56)\end{array}$ & $\begin{array}{c}127 \\
(8.17\end{array}$ & $\begin{array}{c}129 \\
(6.74)\end{array}$ & $\begin{array}{c}143 \\
(7.72)\end{array}$ \\
\hline Female & $\begin{array}{c}10 \\
(0.30)\end{array}$ & $\begin{array}{c}14 \\
(0.40)\end{array}$ & $\begin{array}{c}26 \\
(0.56)\end{array}$ & $\begin{array}{c}33 \\
(0.64)\end{array}$ & $\begin{array}{c}27 \\
(0.44)\end{array}$ & $\begin{array}{c}39 \\
(0.63) \\
\end{array}$ \\
\hline Total & $\begin{array}{c}44 \\
(1.08)\end{array}$ & $\begin{array}{c}57 \\
(1.25)\end{array}$ & $\begin{array}{c}102 \\
(1.71)\end{array}$ & $\begin{array}{c}160 \\
(2.38)\end{array}$ & $\begin{array}{c}156 \\
(1.95)\end{array}$ & $\begin{array}{c}182 \\
(2.26) \\
\end{array}$ \\
\hline \multicolumn{7}{|c|}{$\begin{array}{l}\text { Table 2: Year-Wise Distribution Seroprevalence } \\
\text { Rates of HBsAg and HCVAb }\end{array}$} \\
\hline
\end{tabular}

${ }^{*}$ HBsAg- Hepatitis B virus surface antigen.

$¥$ HCVAb- hepatitis $C$ virus antibody.

\begin{tabular}{|c|c|c|c|c|c|c|}
\hline \multirow{2}{*}{$\begin{array}{l}\text { Age } \\
\text { Group }\end{array}$} & \multicolumn{2}{|c|}{$\begin{array}{c}\text { HBsAg } \\
\text { Positive }\end{array}$} & \multicolumn{2}{|c|}{$\begin{array}{c}\text { HCVAb } \\
\text { Positive }\end{array}$} & \multicolumn{2}{|c|}{$\begin{array}{c}\text { HBsAg } \\
+ \text { +HCVAb } \\
\text { Positive }\end{array}$} \\
\hline & $\begin{array}{c}M \\
(250)\end{array}$ & $\begin{array}{c}F \\
(238)\end{array}$ & $\begin{array}{c}M \\
(552)\end{array}$ & $\begin{array}{c}F \\
(149)\end{array}$ & $\begin{array}{c}M \\
(43)\end{array}$ & $F(12)$ \\
\hline $0-10$ & 0 & $\begin{array}{c}7 \\
(2.9)\end{array}$ & $\begin{array}{c}1 \\
(0.2)\end{array}$ & 0 & 0 & 0 \\
\hline $11-20$ & $\begin{array}{l}20 \\
(8)\end{array}$ & $\begin{array}{c}32 \\
(13.4)\end{array}$ & $\begin{array}{c}3 \\
(0.5)\end{array}$ & $\begin{array}{c}5 \\
(3.3)\end{array}$ & $\begin{array}{c}1 \\
(2.3)\end{array}$ & 0 \\
\hline $21-30$ & $\begin{array}{c}33 \\
(13.2)\end{array}$ & $\begin{array}{c}91 \\
(38.2)\end{array}$ & $\begin{array}{c}33 \\
(5.9)\end{array}$ & $\begin{array}{c}26 \\
(17.4)\end{array}$ & $\begin{array}{c}7 \\
(16.3)\end{array}$ & $\begin{array}{c}4 \\
(33.3)\end{array}$ \\
\hline $31-40$ & $\begin{array}{c}71 \\
(28.4)\end{array}$ & $\begin{array}{c}75 \\
(31.5)\end{array}$ & $\begin{array}{c}203 \\
(36.7)\end{array}$ & $\begin{array}{c}57 \\
(38.2)\end{array}$ & $9(21)$ & $6(50)$ \\
\hline $41-50$ & $\begin{array}{c}93 \\
(37.2)\end{array}$ & $\begin{array}{c}10 \\
(4.2)\end{array}$ & $\begin{array}{c}257 \\
(46.5)\end{array}$ & $\begin{array}{c}27 \\
(18.1)\end{array}$ & $\begin{array}{c}19 \\
(44.1)\end{array}$ & $\begin{array}{c}1 \\
(8.3)\end{array}$ \\
\hline $51-60$ & $\begin{array}{c}27 \\
(10.8)\end{array}$ & $\begin{array}{c}21 \\
(8.8)\end{array}$ & $\begin{array}{c}51 \\
(9.2)\end{array}$ & $\begin{array}{c}16 \\
(10.7)\end{array}$ & $\begin{array}{c}5 \\
(11.6)\end{array}$ & $\begin{array}{c}1 \\
(8.3)\end{array}$ \\
\hline $61-70$ & $5(2)$ & $\begin{array}{c}7 \\
(2.9)\end{array}$ & $\begin{array}{c}3 \\
(0.5)\end{array}$ & $\begin{array}{c}11 \\
(7.3)\end{array}$ & $\begin{array}{c}2 \\
(4.6)\end{array}$ & 0 \\
\hline $\begin{array}{c}71 \& \\
\text { Above }\end{array}$ & $\begin{array}{c}1 \\
(0.4)\end{array}$ & 0 & $\begin{array}{c}1 \\
(0.2)\end{array}$ & $\begin{array}{c}7 \\
(4.6)\end{array}$ & 0 & 0 \\
\hline \multicolumn{7}{|c|}{$\begin{array}{l}\text { Table 3: Seropositivity Rates of HBsAg } \\
\text { and HCVAb in Different Age-Groups }\end{array}$} \\
\hline
\end{tabular}

\section{DISCUSSION}

Out of 37417 serum samples studied, a majority of 28436 (76\%) were from patients registered at the OPD and the rest were from those admitted in the wards (Table 1). A majority of $22180 \quad(78 \%)$ samples were from asymptomatic individuals and 8231 (22\%) had complaints related to viral hepatitis as icterus with or without fever, anorexia, nausea, vomiting, right upper quadrant abdominal pain and hepatomegaly. Among the 27296 female patients, most of them 22109 (81\%) were females undergoing antenatal screening for Hepatitis B and C infections. 
A much lesser $245(0.9 \%)$ of them were undergoing pre-operative screening and none of them revealed a history of being HIV positive. Of the 10121 males, 435 (4.3\%) were known HIV positive patients and 1214 (12\%) were screened pre-operatively.

Out of 10121 males screened, it has been found that 250 (2.4\%) of them were only HBsAg positive whereas a much higher $552(5.4 \%)$ tested positive for only HCVAb. Out of 27296 females studied, $238(0.8 \%)$ and $149(0.5 \%)$ of them were only HBsAg and only HCVAb positive respectively. 43 $(0.4 \%)$ males and $12(0.04 \%)$ females were positive for both infections and all were found to be symptomatic for viral hepatitis. Though it could not be determined whether these were co-infections or super-infections, it is known that both lead to high morbidity and mortality.[1] HBsAg in serum is the first seromarker to indicate active HBV infection, either acute or chronic. Based on the prevalence of chronic hepatitis B, countries have been variably classified as high $(\geq 8 \%)$, intermediate $(2-7 \%)$, and low prevalence $(\leq 2 \%)$ areas. ${ }^{2]}$

India has been placed in the intermediate zone of prevalence by WHO.[3] In this study, the yearly seroprevalences among the males ranged from 1.55 to $2.38 \%$ whereas those among the females ranged from 0.66 to $1 \%$ (Table 2). Comparing the HBsAg seropositivity rates in different age groups, we can observe that they are higher among the females up to 30 years of age. Thereafter, the seropositivity rates start to reverse and the percentage of positive males predominate (Table 3 ).

Among the $293 \mathrm{HBsAg}$ positive males, 80 (27.3\%) were in the 31-40 years age-group and 112 (38.2\%) were in the 41-50 years age-group. Considering the fact that all of the known HIV positive males belonged to these two age-groups, and that most HIV positives in this state are or were intravenous drug users (IVDUs), it is easy to understand why more number of males were positive in these two agegroups. ${ }^{[4]}$ Beyond these two age-groups, the numbers of HBsAg positive males are much lower at $40(13.65 \%)$ and 29 $(9.8 \%)$ in the 21-30 and 51-60 years age-groups respectively.

Comparing the HBsAg seropositivity rates in different age-groups of $137 \mathrm{HBsAg}$ positive females, we observed that a maximum of $176(70 \%)$ are in the $21-30$ and $31-40$ year age-groups put together. Taking into consideration the high percentage $(81 \%)$ of pregnant females among the total number of females screened, this high rate of seropositivity in the child bearing age is expected to translate into high perinatal transmission rates. Perinatal transmission is the most common mode of HBV transmission worldwide.

Neonatal vaccination prevents new born infection in about $80-95 \%$ of cases.[5] Centers for Disease Control and Prevention (CDC) guidelines include mandatory screening of all women for hepatitis B during the first prenatal visit because this virus is highly contagious, and the risk that the newborn infant will develop hepatitis B is $10-20 \%$ if the mother is positive for HBsAg.[6] $\mathrm{CDC}$ also noted that risk factor-based screening did not identify $35-65 \%$ of all HBsAg positive mothers. Thus, screening the expectant mother could go a long way in prevention of prenatal HBV transmission. In India, unlike the policy for HIV infection screening among pregnant women, there is no policy for HB infection screening for them.

Perinatal transmission of HBV infection has declined steadily in United States, consistent with the successful implementation of universal screening of pregnant women and vaccination policies.[7] If the mother is HBsAg positive, appropriate active and passive immunoprophylaxis should be given in the form of hepatitis $B$ immunoglobulin and hepatitis $B$ vaccine.

The presence of HCVAb indicates previous exposure to hepatitis C virus. This antibody is present in only $40 \%$ of acute infections but in more than $95 \%$ of chronic infections. [8] Hepatitis C (HCV) infection establishes a state of chronic infection in as many as $85 \%$ of acutely infected patients, whereas about $15 \%$ of acutely infected patients spontaneously clear the infection. ${ }^{[9]}$ In India, HCV antibodies are present in approximately 15 million people with a prevalence rate of $1.2-1.8 \%{ }^{[10,11]}$ In this study, the yearly overall seroprevalence ranged from $1.08 \%$ to $2.38 \%$. Those among the females continued to be under $1 \%$. In contrast, those among the males could be due to the fact that this institute runs an Anti-retroviral Therapy (ART) centre under the aegis of the National AIDS Control Organisation (NACO).

In Manipur, HIV-HCV co-infection among people living with HIV (PLHIV) was 79.1\% in 2008.[4] In India, HCV is the most infectious disease among IVDUs. A recent study conducted in another medical institute in the same city reported the seroprevalence of HCVAb as $0.40 \%$ among the voluntary blood donors and $1.11 \%$ among the replacement/relative blood donors.[12] Evidently more lives could be lost due to HCV than with HIV among people who have or had treatment, high risk behaviour such as sharing of needles and syringes, and also of other injecting-related equipment, because the cost of treatment is very high and there is no Government policy to screen these patients as in the case of HIV/AIDS.

On the other hand, universal screening for hepatitis $\mathrm{C}$ in pregnancy is not recommended. Firstly, the efficiency of hepatitis $\mathrm{C}$ virus (HCV) transmission by sexual activity remains controversial.[13] Secondly, an effective hepatitis C vaccine has not been developed and thirdly, the drugs used most commonly to treat hepatitis $\mathrm{C}$ in both children and adults, interferon and ribavirin, are not recommended for use in pregnancy.[14,15] HCV-infected children may be born to mothers who were HCVAb positive. Intrapartum infection is more common than in-utero infection.[16] Elective caesarean section is not recommended as even non-viremic women cannot be assured they have no chance of infecting their neonates, although the risk appears to be very low.[16,17] Yet, in this study, a large number of pregnant females were screened for HCVAb as clinicians have a tendency to test both HBV and HCV infections together.

In this study, $855(12 \%)$ of 10120 males and 243 (4.7\%) of 5187 non-pregnant females underwent preoperative screening for those two infections. Out of 855 males, only $8(0.93 \%)$ and $2(0.23 \%)$ were positive for HCVAb and HBsAg respectively. Only $1(0.67 \%)$ of the 149 females were reactive for $\mathrm{HBsAg}$. It has been suggested that a minimum prevalence of 1 in $1000(0.1 \%)$ in the general population justifies screening of an infection.[18] Universal pre-operative testing for HBV and HCV may be done if a protocol for management of infected patients, including testing of family members of confirmed cases, is available as non-sexual intra-familial modes of transmission of HBV and HCV have been reported.[19,20,21] 
Patient and institutional resources may be saved by elective screening dependent on a carefully worked out clinical risk assessment plan.

\section{CONCLUSION}

This study shows that the rising seroprevalence rates of hepatitis B and C infections, especially that of HCV infection among the males, is a cause of alarm in this state of north eastern India bordering Myanmar. Taking into consideration that there is no vaccine or immunoglobulin prophylaxis for hepatitis $\mathrm{C}$ infection, and that screening is justified in terms of the seroprevalence rates of both infections, a large study among the general population could be conducted to make the consideration for national policies for both forms of hepatitis more conclusive.

\section{REFERENCES}

1. Jain P, Prakash S, Gupta S, et al. Prevalence of hepatitis A virus, hepatitis $B$ virus, hepatitis $C$ virus, hepatitis $D$ virus and hepatitis $E$ virus as causes of acute viral hepatitis in North India: a hospital based study. Indian J Med Microbiol 2013;31(3):261-5.

2. Lok ASF, McMahon BJ. Chronic hepatitis B: update 2009. Hepatology 2009;50(3):661-2.

3. Sood S, Malvankar S. Seroprevalence of hepatitis B surface antigen, antibodies to the hepatitis $C$ virus and human immunodeficiency virus in a hospital-based population in Jaipur, Rajasthan. Indian J Community Med 2010;35(1):165-9.

4. http://www.ihra.net/global-state-of-harm-reductionreports. Last accessed on Feb 24, 2016.

5. Jonas MM. Hepatitis B and pregnancy: an underestimated issue. Liver Int 2009;29(Suppl 1):133-9.

6. Centers for Disease Control (CDC). Prevention of perinatal transmission of hepatitis B virus: prenatal screening of all pregnant women for hepatitis B surface antigen. MMWR Morb Mortal Wkly Rep 1988;37(22):341-6, 351.

7. Mast EE, Weinbaum CM, Fiore AE, et al. A comprehensive immunization strategy to eliminate transmission of hepatitis B virus infection in the United States: recommendations of the advisory committee on immunization practices (ACIP) part II: immunization of adults. MMWR Recomm Rep 2006;55(RR-16):1-25.

8. Baheti R, Gehlot RS, Baheti R. Seroprevalence of anti HCV $\mathrm{Ab}$ in healthy voluntary blood donors and in high risk individuals. J Indian Assoc Community Med 2000;1:230-2.
9. Karki S, Ghimere P, Tiwari BR, et al. Trends in hepatitis B and $C$ seroprevalence among Nepalese blood donors. Jpn J Assoc Community Med 2000;1:230-2.

10. Panigrahi AK, Panda SK, Dixit RK, et al. Magnitude of hepatitis $C$ virus infection in India: prevalence in healthy blood donors, acute and chronic liver disease. J Med Virol 1997;51(3):167-74.

11. Batham A, Narula D, Toteja T, et al. Systematic review and meta-analysis of prevalence of hepatitis B in India. Indian Paediatr 2007;44(9):663-74.

12. Lalhriatpuii ST, Sharma AB, Singh AM, et al. Hepatitis $C$ virus seroprevalence among blood donors in a tertiary hospital in Manipur. International Journal of Innovative Research and Development 2014;3(1):190-2.

13. Terrault NA, Dodge JL, Murphy EL, et al. Sexual transmission of hepatitis $\mathrm{C}$ virus among monogamous heterosexual couples: the HCV partners study. Hepatology 2013;57(3):881-9. doi: 10.1002/hep.26164.

14. McIntyre PG, Tosh K, McGuire W. Caesarean section versus vaginal delivery for preventing mother to infant hepatitis C virus transmission. Cochrane Database Syst Rev 2006;(4):CD005546.

15. Paccagnini S, Principi N, Massironi E, et al. Perinatal transmission and manifestation of hepatitis $\mathrm{C}$ virus infection in a high risk population. Paediatr Infect Dis J 1995;14(3):195-9.

16. Resti M, Bortolotti F, Vajro P, et al. Guidelines for the screening and follow-up of infants born to anti-HCV positive mothers. Dig Liver Dis 2003;35(7):453-7.

17. Mohan N, Gonzalez-Peralta RP, Fuijisawa T, et al. Chronic hepatitis $\mathrm{C}$ virus infection in children. Jour Paediatr Gastroent 2010;50(2):123-31.

18. Thorton AC, Delpech V, Kall MM, et al. HIV testing in community settings in resource-rich countries: a systematic review of the evidence. HIV Med 2012;13(7):416-26.

19. Gupta S, Gupta R, Joshi YK, et al. Role of horizontal transmission of hepatitis $B$ virus spread among household contacts in north India. Intervirology 2008;51(1):7-13.

20. Thakur V, Kazim SN, Guptan RC, et al. Molecular epidemiology and transmission of hepatitis $\mathrm{B}$ virus in close family contacts of HBV-related chronic liver disease patients. J Med Virol 2003;70(4):520-8.

21. Sood A, Midha V, Sood N, et al. Prevalence of anti-HCV antibodies among family contacts of hepatitis $\mathrm{C}$ virusinfected patients. Indian J Gastroenterol 2002;21(5):1857. 